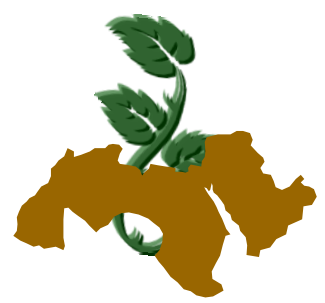

Arab Univ.

J. Agric. Sci., Ain Shams Univ., Cairo, 16(2), 419-426, 2008

\title{
SENSORIAL TEXTURE ATTRIBUTES OF "RAS"CHEESE IN RELATION TO ITS PHYSICO-CHEMICAL PROPERTIES AS COMPARED WITH SOME MARKET IMPORTED CHEESES AT DIFFERENT AGES
}

\author{
Abd El-Aziz, M. ${ }^{1,}$; Faten, L. Seleet ${ }^{1}$ and A. A. El-Nimr ${ }^{1}$ \\ 1- Dairy Science Department, National Research Centre (NRC), Dokki, Cairo, Egypt \\ a E-mail: m_abdalaziz3@yahoo.com
}

Keywords: Sensory cheese texture, Egyptian Ras cheese, Cheese physico-chemical properties

\section{ABSTRACT}

Sensorial textural of cheese could be affected more or less by different physico-chemical changes happened in the viscoelastic systems. Correlations between sensorial textural and physicochemical properties of Egyptian "Ras" cheese in comparison with some market imported cheeses at different ages of ripening were studied. Two groups of Egyptian "Ras" cheese being mild ( 4 months old) and over ripened ( 12month old) were compared with three imported Australian cheese varieties being Cheddar ( 6 months old), Edam ( $\sim$ months old) and Gouda ( 3 months old). Seven expert judges, identified 7 textural mouth terms and 3 textural hand terms for sensory evaluation of all cheese types. Ras cheese (mild or ripened) showed higher firmness and salt/water phase $(\mathrm{S} / \mathrm{W})$, but were lower in moisture content, water activity (aw) than imported cheese types. Ras cheese characterized as lower in: degree of hand rate of recovery, cohesiveness, adhesiveness, mass smoothness and residual smoothness, while as higher in: degree of breakdown and first bite fracturability in the mouth. Differentiations in texture parameters between different cheese types were affected to far extent by S/W phase, aw, moisture content as well as water soluble nitrogen (WSN) related to total protein. In addition, most of sensory terms were directly correlated with each others.

\section{INTRODUCTION}

Texture is an important characteristic used to differentiate many cheese varieties and is considered by the consumer to be the limitative factor of overall quality and preference (Guinard \& Maz- zucchelli, 1996; Antoniou et al 2000 and Wendin et al 2000). Cheese texture can be evaluated using instrumental texture profile analysis (TPA) or sensorial textural attributes. Sensory evaluations of cheese texture extensive have often been chosen for routine texture measurements. Many empirical and imitative instrumental tests have been developed to correlate with sensory texture descriptors (Drake et al 1999b).

Numerous studies have focused on correlating sensory texture attributes of some hard cheese types (Cheddar, Parmesan and Gouda cheeses) with instrumental TPA (Drake et al 1999a and Brown et al 2003). However, few studies have attempted to correlate these sensorial and instrumental tests with physico-chemical properties, while no studies focused on texture attributes of Egyptian Ras cheese, which is the most dominate hard cheese in Egypt. Ras cheese is made from raw cow's milk or a mixture of cow's and buffalo's milks (Awad, 2006).

The aim of this study was to determine the relationships between physico-chemical properties of Egyptian "Ras" cheese and its sensorial texture attributes in comparison with some market imported cheeses at different stages of ripening.

\section{MATERIALS AND METHODS}

\section{Cheese samples}

Cheese samples were randomly collected from Egyptian market at Greater Cairo governorates, being: mild Ras cheese (6 samples, $\sim 4$ months old), over ripened Ras cheese (6 samples, $\sim 12$ months old), Australian Cheddar cheese (8 samples, $\sim 6$ months old), Australian Edam cheese (6 samples, $\sim 4$ months old) and Australian Gouda cheese (6 samples, $\sim 3$ months old). 


\section{Methods}

\subsection{Chemical analysis}

Moisture content was determined according to AOAC (2000). The $\mathrm{pH}$ value was measured using digital $\mathrm{pH}$ meter (HANNA, Instrument, Portogal) with glass electrode. Total nitrogen content (TN) was determined by Kjeldahl method (AOAC, 2000). The protein content was obtained by multiplying the percentage of total nitrogen content by 6.38. Salt content in cheese was determined and estimated as $\mathrm{NaCl}$ as in Richardson (1985). Water soluble nitrogen (WSN) was extracted according to Coskum and Tuncturk (2000) as follow: 20 $\mathrm{g}$ cheese was mixed thoroughly with distilled water (2:8), hold at $40{ }^{\circ} \mathrm{C}$ for $1 \mathrm{hr}$ and then centrifuged at $3000 \mathrm{xg}$ for $30 \mathrm{~min}$. The extract was filtered and the filtrate was used for determination of WSN. Phosphotungestic acid- soluble nitrogen (PTA-SN), was measured as tri-di-peptides and free amino acids (Coskum and Tuncturk (2000) as follow: 10 $\mathrm{ml}$ of WSN extract were taken and $7 \mathrm{ml} 3.95 \mathrm{M}$ $\mathrm{H}_{2} \mathrm{SO}_{4}$, and $3 \mathrm{ml} 33 \%(\mathrm{w} / \mathrm{v})$ Phosphotungstic acid were added. The mixture was held at $4^{\circ} \mathrm{C}$ for $12 \mathrm{hr}$, then filtered through Whatman No. 40, and after that, nitrogen content of the filtrate was determined. All analyses were performed in triplicate.

\subsection{Water activity $\left(a_{w}\right)$}

Water activity $\left(\mathrm{a}_{\mathrm{w}}\right)$ was measured using Rotronic-Hygroskop (ROTRONIC- HYGROSKOP DT, USA). A Rotronic instrument was calibrated by Lithium Chloride solution $(80 \% \mathrm{RH})$ at $25^{\circ} \mathrm{C}$.

\subsection{Firmness}

A Shimadzu Testing Instrument (model 1195, USA) was used to measured cheese firmness. Cheese sample was tempered for $1 \mathrm{hr}$ at $25^{\circ} \mathrm{C}$ and plug of cheese $(20 \mathrm{~mm}$ high and $13 \mathrm{~mm}$ in diameter) was cut just before it was evaluated. Sample was compressed at $25^{\circ} \mathrm{C}$ with across heated speed of $10 \mathrm{~mm} / \mathrm{min}$. Full scale load was $10 \mathrm{~kg}$ and sample was compressed to $50 \%$ of its initial height. The firmness was measured twice for each sample.

\subsection{Descriptive analysis}

Seven expert judges, staff member (males, and females) Food and Dairy Science, National Research Center, Egypt, who had previous experi- ence with textural descriptive testing of different cheese types, were evaluated cheese samples. Sensory attribute terms were fully explained and well defined in 10 training sessions, till the agreement between all subjects was satisfied. Samples were cut into cubes $(1.5 \times 1.5 \times 1.5 \mathrm{~cm})$ and covered with plastic wrap to prevent dehydration. Cheese samples were obtained from the middle of the hole cheese block rather than the surface to avoid surface effects. Samples were held at least 1 $\mathrm{hr}$ at $20^{\circ} \mathrm{C}$ to equilibrate. Each judge was given six cubes of cheese per samples. Judges were given water and napkins for mouth and hand cleaning and were asked to expectorate all samples in order to measure residual mouthfeel. Descriptive analysis was used to identify perceived texture characteristics of cheese. The texture perception, evaluation technique terms definition are outlined in (Table 1) as given by Brown et al (2003). Quantifications of percept sensorial textural attributes were scaled on 5 points level referring to Maifren et al (2002).

\section{Statistical analysis}

Statistical analyses were performed using the SPSS (2002) software. One-way analysis of variance and Duncan's test were performed to ascertain whether the chemical, physical and sensory parameter were able to differentiate between the different cheese samples. The Pearson's Correlation coefficients $(R)$ were calculated between all the parameters to determine whether relationships existed between them. The relationship between the sensory characteristics and the physical parameters of cheeses was investigated using multiple regressions. Also degree of strength of this relationship was expressed by $R^{2}$.

\section{RESULTS AND DISCUSSION}

\section{Physico-chemical properties}

The differentiation in physico-chemical properties of hard cheese types are presented in Table (2). Ras cheese had highest instrumental firmness as well as fat/DM and salt/water phase (S/W phase) contents, while it had lowest $a_{w}$ and moisture content $(P<0.05)$ as compared with Gouda and Edam cheeses. Conversely, Gouda cheese had more moisture content, more water soluble nitrogen (WSN), less instrumental firmness and less S/W phase compared to other hard cheese types. 
Table 1. Mouth and hand texture terms definition and technique (Brown et al 2003)

\begin{tabular}{|c|c|c|}
\hline $\begin{array}{c}\text { Term } \\
\text { (abbreviation) }\end{array}$ & Definition & Technique \\
\hline $\begin{array}{l}\text { Hand firmness } \\
\text { (hfm) }\end{array}$ & $\begin{array}{l}\text { The amount of force required to com- } \\
\text { pletely compress the sample. }\end{array}$ & $\begin{array}{l}\text { Press completely through the sample } \\
\text { using the thumb and first tow figures. }\end{array}$ \\
\hline $\begin{array}{l}\text { Hand springiness } \\
\text { (hsp) }\end{array}$ & $\begin{array}{l}\text { The total amount of recovery of the } \\
\text { sample. }\end{array}$ & $\begin{array}{l}\text { Press the sample between the thumb } \\
\text { and first tow figures until it is depressed } \\
30 \% \text {. }\end{array}$ \\
\hline $\begin{array}{l}\text { Hand rate of } \\
\text { recovery } \\
\text { (hrc) }\end{array}$ & $\begin{array}{l}\text { The speed at which the sample re- } \\
\text { turns to its original shape. }\end{array}$ & $\begin{array}{l}\text { Press the sample between the thumb } \\
\text { and first tow figures until it is depressed } \\
30 \% \text {. }\end{array}$ \\
\hline $\begin{array}{l}\text { First bite firmness } \\
(\mathrm{ffm})\end{array}$ & $\begin{array}{l}\text { The amount of force required to com- } \\
\text { pletely bite through the sample. }\end{array}$ & $\begin{array}{l}\text { Completely bite through the sample } \\
\text { using the molars. }\end{array}$ \\
\hline $\begin{array}{l}\text { First bite } \\
\text { fracturability } \\
(\mathrm{ffm})\end{array}$ & $\begin{array}{l}\text { The amount of fracturability in the } \\
\text { sample after biting. }\end{array}$ & $\begin{array}{l}\text { Completely bite through the sample } \\
\text { using the molars. }\end{array}$ \\
\hline $\begin{array}{l}\text { Chewdown degree } \\
\text { of breakdown } \\
\text { (chr) }\end{array}$ & $\begin{array}{l}\text { The amount of breakdown that occurs } \\
\text { in the sample as a result of mastica- } \\
\text { tion (i.e. the amount of meltability or } \\
\text { dissolvability). }\end{array}$ & $\begin{array}{l}\text { Chew the sample } 5 \text { times and evaluate } \\
\text { the chewed mass. }\end{array}$ \\
\hline $\begin{array}{l}\text { Chewdown } \\
\text { cohesiveness } \\
\text { (cco) }\end{array}$ & $\begin{array}{l}\text { The degree to which the chewed mass } \\
\text { holds together. }\end{array}$ & $\begin{array}{l}\text { Chew the sample } 5 \text { times and evaluate } \\
\text { the chewed mass. }\end{array}$ \\
\hline $\begin{array}{l}\text { Chewdown } \\
\text { adhesiveness } \\
\text { (cad) }\end{array}$ & $\begin{array}{l}\text { The degree to which the chewed mass } \\
\text { sticks to mouth surfaces. }\end{array}$ & $\begin{array}{l}\text { Chew } 5 \text { times and evaluate the chewed } \\
\text { mass. }\end{array}$ \\
\hline $\begin{array}{l}\text { Chewdown } \\
\text { smoothness of } \\
\text { mass } \\
(\mathrm{csm})\end{array}$ & $\begin{array}{l}\text { The degree to which the chewed mass } \\
\text { surface is smooth (i.e. evaluation for } \\
\text { gritty or grainy particles). }\end{array}$ & $\begin{array}{l}\text { Chew the sample } 5 \text { times and evaluate } \\
\text { the chewed mass. }\end{array}$ \\
\hline $\begin{array}{l}\text { Residual } \\
\text { smoothness of } \\
\text { mouth coating } \\
\text { (rsm). }\end{array}$ & $\begin{array}{l}\text { The degree of smoothness felt in the } \\
\text { mouth after expectorating the sample. }\end{array}$ & $\begin{array}{l}\text { Chew the sample } 5 \text { times, expectorat- } \\
\text { ing, and evaluate the residual in the } \\
\text { mouth. }\end{array}$ \\
\hline
\end{tabular}

However, the result did not show significant differences in physico-chemical properties between Gouda and Edam cheeses, except in $\mathrm{pH}$ values as well as WSN and S/W phase contents. Whereas, Edam cheese had higher $\mathrm{pH}$ value and $\mathrm{S} / \mathrm{W}$ phase content $(P<0.05)$, and lowest WSN content $(P<0.05)$ than Gouda cheese. Also, the differences between mild Ras cheese and Cheddar cheese were insignificant, except in $\mathrm{a}_{\mathrm{w}}$ and $\mathrm{S} / \mathrm{W}$ phase content. Concerning to Ras cheese types, over ripened Ras cheese had significantly higher instrumental firmness as well as WSN, PTA and S/W phase contents, while lower $\mathrm{a}_{w}$ and moisture content than mild Ras cheese. These results may be related to the moisture loss and/or water redistribution within aged Ras cheese network, hence, increase S/W phase content, which has more effect on cheese firmness.

\section{Sensorial texture attributes}

It could be noticed from Table (3) that Ras cheese had more hand firmness (as measured by hand) and first bite firm (as measured by mouth) than other hard cheese types. Also, Ras cheese appeared to breakdown more in mouth after chewdown over time, while less hand rate of recovery, cohesiveness, adhesiveness, mass smoothness and residual smoothness in the mouth compared to other cheese types. These differences were significant $(\mathrm{P}<0.05)$ if compared with Gouda and Edam cheeses. However, the differences in sensorial textural attributes between Edam and Gouda cheeses were insignificant $(P>0.05)$. Concerning to Ras cheese groups, over ripened Ras cheese, which had higher WSN content (Table 2), showed higher instrumental firmness, hand firmness and 
first bite firm (Table 3), than mild Ras cheese. Also, over ripened Ras cheese recorded less hand rate of recovery, while more breakdown, cohesiveness, adhesiveness, mass smooth and residual smooth over time than mild Ras cheese. Moreover, sensorial texture attributes of Cheddar cheese lies between Gouda and Ras cheeses.

\section{Relationships between physico-chemical and sensory terms}

Instrumental firmness and S/W phase were highly negatively correlated with hand rate of recovery, cohesiveness, mass smoothness and residual smoothness in the mouth, while positively correlated with hand firmness and breakdown (Table 4). These correlations are in agreement with Hort et al (1997) who mentioned that low percentage $S / W$ phase have been found to produce a "weak and pasty" cheddar cheese, whereas higher concentration produce an excessively "firm" body. Firmness measurements (as measured by instrumental, hand and mouth) and breakdown were negatively correlated with moisture content and $\mathrm{a}_{\mathrm{w}}$. However, moisture content and $a_{w}$ were positively correlated with hand rate of recovery, cohesiveness, mass smoothness and residual smoothness in the mouth. Fox et al (2000) stated that, the decreasing of moisture content acts as a plasticizer in the protein matrix, thereby making it less elastic and more susceptible to fracture upon compression. Moreover, correlation coefficient show that, fat/DM content has adverse effect on hand firmness and hand rate of recovery, while has positive effect on breakdown, cohesiveness, mass smoothness and residual smoothness in the mouth. WSN content was also highly correlated with cohesiveness, mass smoothness and residual smoothness in the mouth. These observations are confirmed by the results of regression coefficient $\left(R^{2}\right)$ as shown in Table (4).

\section{Relationships among sensory terms}

Table (5) shows the correlation coefficient and regression coefficient $\left(R^{2}\right)$ among sensorial texture attributes of hard cheese types. Hand firm was correlated with breakdown, showing that the firmer cheese tend to fracture into pieces when force was add. Also, hand firmness was negatively correlated with most sensory terms, such as, cohesiveness, adhesiveness, mass smoothness and residual smoothness in the mouth, while it was positively correlated with first bite firm (Table 5). Negative correlations were also observed between breakdown, and cohesiveness, mass smooth and resid- ual smooth (Table 5). These results implying that when cheeses fractured into many pieces upon biting, those pieces maintained their individually as one chewed (Brown et al 2003). In addition, mass smoothness and residual smoothness in the mouth were highly correlated with cohesiveness, but not to the same degree with adhesiveness. Similar relationships reported by Brown et al (2003). Drake et al (1999a) mentioned that, cohesive cheeses would generally be smooth and slippery in mouthfeel. However, positive correlations of hand rate of recovery with cohesiveness, mass smoothness and residual smoothness in the mouth were observed. Conversely, negative correlation was found between hand rate of recovery and hand firmness. This correlations disagreement with Drake et al (1999b) who stated that sensorial firm cheese showed a positive correlation with percent creep (crp) a measurement of how much a sample returns to its original shape after reaching full strain in a given time period.

\section{CONCLUSION}

Physico-chemical and sensorial texture attributes were able to differentiate the cheese by variety and by age. Moisture content, aw, S/W phase, and WSN have the major role in defining sensorial texture attributes of hard cheese types, especially Ras cheese. Sensory terms (hand and mouth), such as hand firmness, first bite firm, cohesiveness, hand rate of recovery, mass smoothness and residual smoothness in the mouth were directly correlated with each others. Cheddar, Gouda, Edam cheeses which have significant lower S/W phase, while higher moisture content and $a_{w}$, showed higher cohesiveness, mass smoothness and residual smoothness in the mouth than Ras cheese (mild or over ripened). Ras cheese characterized with firmer texture and breakdown more in mouth after chewdown, but lower in cohesiveness, adhesiveness, mass smoothness and residual smoothness in the mouth than other cheese types.

\section{REFERENCES}

AOAC (2000). Association Official Analytical Chemists. Official Methods of Analysis, $17^{\text {th }} \mathrm{Ed}$. Washington, DC, USA.

Antoniou, K.D.; R. Petridis; S. Raphaelides; Z. Ben Omar and R. Kesteloot (2000). Texture assessment of French cheeses. J. Food Sci., 65: 168-172. 
Awad, S. (2006). Texture and flavour development in Ras cheese made from raw and pasteurized milk. Food Chem., 97: 394-400.

Brown, J.A.; A.E. Foegeding; C.R. Daubert; M.N. Drake and M. Gumpetzt (2003). Relationships among rheological and sensorial properties of young cheeses. J. Dairy Sci., 86: 3054-3067.

Coskum, H. and Y. Tuncturk (2000). The effect of Allium sp. on the extension of lipolysis and proteolysis in Van herby cheese during maturation. Nahrung, 44: 52-55.

Drake, M.A.; P.D. Gerard and G.V. Civille (1999a). Ability of hand evaluation versus mouth evaluation to differentiate texture of cheese. J. Sensory Stud., 14: 425-441.

Drake, M.A.; P.D. Gerard; V.D. Truong and C.R. Daubert (1999b). Relationship between instrumental and sensory measurements of cheese texture. Journal of Texture Stud., 30: 451-476.

Fox, P.F.; T.P. Guinee; T.M. Cogan and P.L.H. McSweeney (2000). Fundamentals of Cheese Science. Cheese Rheology and Texture, pp. 298-340. Aspen Publisher Inc., Gaithersburg, M.D., USA.
Guinard, J.X. and R. Mazzucchelli (1996). The sensory perception of texture and mouthfeel. Trends in Food Sci. \& Technol., 7: 213-219.

Hort, J.; G. Grys and J. Woodman (1997). The relationships between the chemical, rheological and textural properties of cheddar cheese. Lait, 77: 587-600.

Maifren, M.; M. Marino; P. Pittia and G. Rondinini (2002). Textural and sensorial characterization of Montasio cheese produced using proteolytic starters. Milchwissenschaft, 57: 23-26.

Richardson, G.H. (1985). Standard Methods of the Examination of Dairy Products. 15 Ed. American Public Health Association. Washington, DC.

SPSS. (2002). Statistical Package for Social Science (Version 11.5). US Government User's, SPSS Inc.

Wendin, K.; M. Lanron; L. Coaus and G. Hall (2000). Dynamic analysis of sensory and microstructural properties of cream cheese. Food Chem., 71: 363-378. 